\title{
Article
}

\section{French revolution or peasants' revolt? Petitioners and rebels from the Blanketeers to the Chartists}

\author{
Poole, Robert \\ Available at http://clok.uclan.ac.uk/6682/ \\ Poole, Robert ORCID: 0000-0001-9613-6401 (2009) French revolution or \\ peasants' revolt? Petitioners and rebels from the Blanketeers to the Chartists. \\ Labour History Review, 74 (1). pp. 6-26. ISSN $0961-5652$
}

It is advisable to refer to the publisher's version if you intend to cite from the work. http://dx.doi.org/10.1179/174581809×408375

For more information about UCLan's research in this area go to http://www.uclan.ac.uk/researchgroups/ and search for < name of research Group>.

For information about Research generally at UCLan please go to http://www.uclan.ac.uk/research/

All outputs in CLoK are protected by Intellectual Property Rights law, including Copyright law. Copyright, IPR and Moral Rights for the works on this site are retained by the individual authors and/or other copyright owners. Terms and conditions for use of this material are defined in the policies page.

\section{CLoK}

Central Lancashire online Knowledge www.clok.uclan.ac.uk

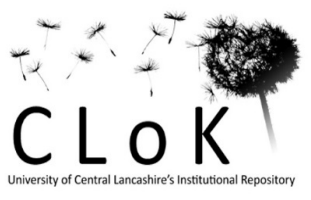




\title{
French ReVolution or Peasants' Revolt? Petitioners and Rebels in England FROM THE BLANKETEERS TO THE CHARTISTS
}

\author{
Robert Poole \\ For Labour History Review, 74, 1 (April 2009).
}

Corrected but not checked against published version.

On Monday 10 March 1817, a crowd of some 25,000 people assembled in Manchester for what would later become a canonical event in the 'forward march of labour': the march of the Blanketeers to London. Although it has sometimes been seen as an early version of the hunger marches of the 1930s, the march had a welldefined political purpose: to deliver a last-ditch appeal for constitutional reform, not to parliament but to the crown. The suspension of Habeas Corpus a few days before had led to the detention or flight of most of the local radical leadership so the meeting was addressed by John Bagguley, an eighteen-year-old machine maker with a newly-discovered talent for oratory. According to a police informer,

Baguley said, This is one of the happiest moments of my life to see you all ready to go [on] so virtuous \& aplaudable a journey. There never was such a thing done before. If you look through all the annals of history you will not see any like this. In the reign of Richard II about 40,000 men went to London to demand their rights of the King; \& he granted them their rights \& they went home again. But they only came a little way from London, they did not go from Manchester.

The marchers were urged to peace, and 'those that can forgive all their enemies, constables \& so [on] that hath been against us' were invited to give a show of hands; nearly all did. Those thousands who had prepared for the march on London, many with knapsacks containing food and blankets, were formed into groups of ten, each with a leader and a petition carrying twenty names. ${ }^{1}$ The meeting was broken up without serious injury by a small force of dragoons. The several hundred 'blanketeers' who did manage to get out of Manchester were intercepted at Macclesfield, Leek and Ashbourne, at various stages along the road towards Derby and London which the Jacobite rebels had taken in 1745. Other abortive risings of obscure provenance followed: at Manchester again in late March, and at Pentridge (near Sheffield) and Folley Hall (near Huddersfield) in June. 
The movements of the post-war years - E. P. Thompson's 'heroic age of popular radicalism' - lie untidily across the tracks of progress. ${ }^{2}$ Much twentiethcentury work reflected the unspoken assumption that British radicals must have been trying either to replicate the French revolution or to anticipate the Russian one. Apart from the fact of rebellion, there is little about the Blanketeers episode that fits either of these models. Parallels with the hunger marches of the 1930s are also of limited value. Thompson himself identified the Pentridge rising as 'one of the first attempts in history to mount a wholly proletarian insurrection'. Whilst admiring the spirit of the endeavour, he stressed the problems faced by would-be insurgents beset by poor communications, rumour, espionage and conspiracy. Had the Blanketeers actually made it to London, he suggested, their effect could have been similar to that of the arrival of the men of Marseilles in Paris in 1792 - a radicalisation of the capital. ${ }^{3}$

While the mass movements of 1819 have been extensively reappraised, the turbulent events of 1817 have not received the same sort of attention. ${ }^{4}$ Comments in textbooks have tended to follow a 'cauldron of discontent' model in which hunger, deprivation and oppression heat the proletarian gruel to boiling point, producing sporadic bubbles of discontent which subside once the economic heat is turned down. The ultimate expression of the progressive view of post-war radicalism appeared in John Foster's 1974 study Class Struggle in the Industrial Revolution. Foster set the bar high, chiding even the movements of the 1830 s and 1840 s for 'lack of Leninist rigour'. He disposed of the events of 1816-20 in a few lines.

1816-17 combined local insurrections with an attempt to overcome the weakness in London by marching south a mass of northern industrial workers. After the failure of this, 1818 saw a return to industrially based activity culminating in a general strike... 1819 moved from a fairly sophisticated (and nationally concerted) plan of mass mobilisation... to an old-style insurrection in April 1820.

In Foster's theology of class struggle, while these movements were 'apparently just as revolutionary' as those that came later, the participants lacked the 'permanence of intellectual commitment' of the class-conscious revolutionary and fell victim instead to a variety of 'sectional false consciousnesses'. In other words, there cannot have been proper revolutionaries because capitalism was not yet developed enough to produce any. This is the condescension of posterity at its most posterior. ${ }^{5}$ Foster's thesis collapsed when careful research by Michael Winstanley demonstrated that Oldham's most uncompromising radicals were Cobbetite weavers and smallholders; 
urban workers gravitated towards liberalism. ${ }^{6}$ Foster's enduring contribution to labour history was to provoke Gareth Stedman Jones to a lengthy critical review and thence to his influential essay 'Rethinking Chartism' which reasserted the importance of politics in the study of popular movements. ${ }^{7}$

The major study of post-war radicalism to date is John Belchem's Orator Hunt. It traces the emergence of the Chartist 'mass platform' strategy to the post-war years, particularly the radical reform movement of 1819 - the year of Peterloo. Whilst maintaining the importance of class with a small ' $c$ ' in fuelling radicalism Belchem emphasises the political element of English popular protest, arguing that 'the mass platform offered a powerful alternative to other patterns of collective violence: the unstructured, non-political violence or "turmoil", characteristic of preindustrial protest; and the elitist, spy-ridden "conspiracies" favoured by the revolutionary underground of the war years'. In 1816-17 he identifies intriguing links between ultra-radicals in London and disturbances in the provinces, but the "hunger march' of the Blanketeers from Manchester and the subsequent risings are not the main subject of his inquiries. ${ }^{8}$

The reform movement of 1817 may seem to have gone off in all directions like a cheap box of fireworks, but it had more underlying coherence than it has usually been given credit for. Radicals used mass petitioning on a national scale, backed by the threat of assembled numbers in both London and the provinces. They deployed historical and constitutional arguments of a kind later familiar to the Chartists, they assembled in a kind of national convention, and they moved rapidly from petitioning parliament through remonstrating with the crown to open insurgency. But, less accommodating to the progressive model of labour history, they showed as much interest in appealing to the crown as in petitioning parliament, they adopted a melodramatic model of confrontation with authority, and their favoured precedent was not the French revolution but the English rebellion of 1381 - the so-called 'peasants' revolt'. If we want to understand where Chartism was coming from, we need to look again at post-war radicalism.

The wars of 1793-1815 should have been followed by peace, prosperity and reform. In 1815-16 however a generation of war was followed by rapid demobilisation, economic slump, and the catastrophic 'lost summer' of 1816. The government's priorities were to repeal the wartime property tax and to protect agriculture through the corn laws - the hated 'bread tax'. The economic servitude of wartime, justified by national survival, was to be perpetuated. The radical analysis was political rather than economic: the corrupt financial beneficiaries of war continued to control the 
state and were rigging the tax system in their own interests whilst denying their victims a political voice. As the founding resolutions of Middleton Union Society in October 1816 stated, the evils afflicting the people were 'the natural effect of ... misrule and misgovernment [which] could not have been pursued, had not the people been deprived of their constitutional rights'. The essential right was defined as 'representation, co-extensive with taxation'. The manifesto was headed with a quotation from Edmund Burke: 'When the affairs of a nation are distracted, private individuals are justified in stepping a little out of their ordinary sphere'. 9

Following an initiative by the exclusive London Hampden Club in June 1816, reform societies were founded across the country. By 3 September, according to the Royton radical William Fitton, there were ten Union societies in the weaving districts to the north and east of Manchester, with activity underway in Manchester and Stockport. It came to the attention of the authorities when it encountered the spy network run by the Bolton magistrate Matthew Fletcher. 'There is not a Village Hamlet or Fold of Houses anywhere but has its periodical Meeting \& Committee', wrote his Oldham colleague William Chippendale. 'There is invariably some one or more of the Royton Agitators at these Meetings. The Activity of these People is to me most astonishing'. A meeting was held in Bolton on 4 September.

Informant mentions a remarkable Instance of Fitton's Rhetoric in his Speech at the Meeting. Speaking of the mode by Petition he strongly recommended that as the most prudent first Step, but if that should prove ineffectual then!!!! At this Point he made a full Stop. After a considerable Pause a Person in the Crowd called out 'what then'? To this no Reply was made except a significant Smile. ${ }^{10}$

The autumn saw a wave of large-scale public meetings. At Manchester on 28 October a meeting of 5-10,000 people met at the Quaker chapel to establish the Manchester Constitutional Society. The boroughreeve? and constables had been asked to convene the meeting, but had declined. With no respectable gentleman willing to chair the meeting the main business was postponed, and the society was set up a week later as the Manchester Union for Parliamentary Reform. ${ }^{11}$ On 2 November William Cobbett issued his famous rallying call 'To the journeymen and labourers of England, Wales, Scotland, and Ireland.' It had been anticipated in Lancashire a month earlier by Joseph Mitchell of Liverpool's melodramatic Address to the People, which was quickly distributed in quantity in the Manchester area. ${ }^{12} \mathrm{On}$ the same day the London Hampden Club met and resolved to draw up a bill for 
taxpayer suffrage - that is, for payers of direct taxes - in time for the Club's spring meeting on the first Saturday in March. The proposal was then to be circulated to a national delegate meeting in London in order that 'the proposed Bill may in consultation with the persons chosen for their experience, and wisdom, and integrity, be rendered as unexceptionable as possible, before it be finally submitted to Parliament. ${ }^{13}$

In November too Mitchell went to London to meet Cobbett and the veteran radical John Cartwright, becoming (with William Benbow) the Lancashire agent for Cobbett's Political Register. ${ }^{14}$ In London the Spencean ultra-radicals promoted a series of mass meetings at Spa Fields, on the eastern edge of the city, to force the issue, securing the services of the orator Henry Hunt. Hunt's vision however was democratic rather than conspiratorial: to build up an irresistible weight of numbers, physically assembled, behind the cause of reform. At the second Spa Fields meeting on 2 December, before Hunt had arrived, a posse of militants attempted to recreate the storming of the Bastile, raiding nearby armourers' shops for weapons and making for the Tower of London; they were headed off and the leaders arrested. The meeting was attended by Mitchell and by other Lancashire reformers, who had arranged to send back early news of events. ${ }^{15}$ On 4 December, with a weavers' strike in progress, it was reported from Oldham: 'All the Country in a Bustle about the News from London. The public mind in the highest agitation and ferment ... all agreed in expressing the fullest determination to have mustered and armed immediately, in case the Disturbance in London had been attended with Success.' The Oldham magistrate, William Chippendale, sent his agents in all directions to find out what was going on.

The person who was sent in the direction of Manchester found the road crowded with groups of people all the way. About midnight they began to draw towards Manchester for the purpose of learning the news brought by the Mail. My informant saw 300 in one group in a street adjoining to the Bridgewater, where the mail stops, all Delegates from the country. When the news was not confirmed their disappointment was extreme. ${ }^{16}$

At this point, as with the Chartists in 1839-42, the initiative passed from London to the provinces. Open meetings of the Manchester Union were held weekly on Monday evenings in large rooms on the edge of central Manchester, regularly attracting hundreds of people. These gatherings would receive news both from London and from local meetings, and would be followed by private committee 
meetings in Manchester in mid-week to press ahead with practical activity. The meeting of Monday 9 December received a letter from the London Hampden Club signed by Sir Francis Burdett MP informing them that the Prince Regent would not grant the reform leaders an audience until 2 March, and requesting that local societies should spend the intervening three months collecting signatures for a petition for parliamentary reform to be presented on that date. According to an informer, when Joseph Johnston asked from the chair, "can you wait quietly till this period, cries of no, no, resounded from all sides'. 'The People of Middleton', it was reported, "have determined not to wait till the second of March for they say before that time we shall all be starved to Death even with all the assistance of the Soup Kettle. ${ }^{17}$

The committee then set about distributing for signature printed copies of the Hampden Club's national petition to the House of Commons. Once again the radicals observed due procedure by submitting a formal requisition to the boroughreeve and constables of Manchester to convene an official public meeting for the same purpose; the authorities' failure to act would then justify independent proceedings. The 1792 Seditious Societies Act had banned national political organizations, including associations of local societies operating through correspondence or delegates, but the right to petition was still respected in principle by government. It was thus essential that the London meeting be constituted as an assembly of legitimately petitioning local bodies, and this tactic was indeed successful in preventing the authorities from breaking it up as they had the 1793 Convention in Edinburgh. ${ }^{18}$ The national petition opened with a constitutional justification, printed across sheets two feet wide above space for seven columns of signatures. It asserted:

That your Petitioners have a full and immovable conviction, a conviction which they believe to be universal throughout the Kingdom, that your Honourable House doth not, in any constitutional or rational sense, represent the Nation:

That when all the People cease to be represented, the Constitution is subverted:

That Taxation without Representation is a state of Slavery.

The petition went on to state the fear that 'unconstitutional Taxation may, in all time to come, be laid on to the utmost extent of human endurance .... through the usurpation of a Borough faction.' Its solution was 'the election of a free Parliament', chosen through 'Representation co-extensive, at the least, with direct Taxation', equitably distributed and renewed annually. ${ }^{19}$ 
On Monday 16 December 1816 a public meeting was held at the weaving village of Middleton. The notice imitated the form of official advertisements for township meetings. It offered economic justification for political action.

To the Public.

The Inhabitants of Middleton and its Neighbourhood, are respectfully informed, that a Meeting will be held ON THE BARROW FIELDS, on Monday the $16^{\text {th }}$ December, Instant, at 12 o'clock, to take into consideration the awfully alarming distress which overwhelms our Country, and to recommend to Major Cartwright, Sir Francis Burdett, \&c. to prepare forthwith, a Draft of a Bill for Parliamentary Reform, and to submit the same to the Deputies of the Petitioning Bodies, before Parliament meets, as it is impossible for the People of this part of the Country, to SUBSIST on their present means, even with the support of the SOUP KETTLE, till the Date fixed by the London Hampden Club, (March $2^{\text {nd }}$ )-and also for the purpose of moving a Petition ONCE MORE to the House of Commons, for such a Reform.

Attendees were urged to bring statements of their sufferings, 'that Corruption may no longer dispute the reality of your Distress.' ${ }^{20}$ The meeting was attended, in atrocious weather, by some 2,000 people, including delegates from a dozen Lancashire towns and from Cheshire and the West Riding. It adjourned indoors to endorse the plan, and arranged to send out missionaries to Yorkshire and elsewhere to rouse opinion. ${ }^{21}$ The speeches were reported to have been 'very violent and particularly against the Prince Regent.' According to Chippendale's agent,

It was stated by Mitchell that he had received a confidential letter from Major Cartwright recommending that one out of every ten Members of the Union the Kingdom thro' should accompany the Petitions - ( $O$ ' the old Rascal). This was talked [over] in the Way of Conversation and was pretty generally disapproved of under an Idea of its being impracticable. In every other point of View it was thought very desirable. There was also a Whisper in the room that the younger Watson is in the Neighbourhood of Manchester. ${ }^{22}$ 
The younger James Watson had led the attempt on the Tower of London two weeks before; the rumour however was unfounded. The meeting's declaration To the People of England was published in Manchester shortly afterwards. ${ }^{23}$

On 30 December the London Hampden Club acceded to the Lancashire request and arranged a national delegate meeting in London for January, a week before parliament was due to meet. On the same day an open meeting of Manchester reformers voted in favour of 'representation co-extensive with taxation.' It was clear from the platform that this meant indirect taxation. Meetings at Middleton and Oldham shortly afterwards both voted explicitly in favour of universal suffrage. ${ }^{24}$ Meetings at all three places then adjourned until the second Monday after the opening of parliament to receive news of the fate of the reform bill which they had sponsored. Among the local delegates selected for the London meeting were the ubiquitous Joseph Mitchell and Samuel Bamford, secretary of the Middleton Hampden Club and future chronicler of the movement. It was reported that friendly societies and sick club boxes were being broken up to provide funds, as it was not expected that these would be needed after the forthcoming shift of power. ${ }^{25}$

The meeting at the Crown and Anchor tavern in The Strand on 22 January 1817 had to choose between two reform bills, one for direct taxpayer suffrage supported by the Hampden Club Committee and one for universal suffrage supported by Orator Hunt and his provincial allies. Cobbett was sceptical about Hunt's bill: how could an electoral register be drawn up? Bamford pointed out that the militia rolls could serve as the electoral register. This version of military citizenship appealed to Cobbett who changed his mind, and the day was carried for Hunt and manhood suffrage. ${ }^{26}$ The bill was triumphantly presented to the Commons at the end of January by Thomas Cochrane, a Nelsonian naval hero, along with a number of petitions for reform from various provincial communities. All were found objectionable, mostly on technical grounds of language or procedure, and left 'to lie on the table'. MPs' dismissive comments about the petitioners' ignorance of the correct modes of address were widely reported. The reformers' best efforts had failed; the House of Commons had refused to even acknowledge their right to petition it. ${ }^{27}$

While in London, a number of provincial delegates discussed tactics with the Spencean ultra-radicals at a meeting described by Bamford in his memoirs. The Home Office spies' reports indicate that 'delegates from the country' were present in a private room at the Cock Inn, Grafton St on 27 or 29 January, where they discussed co-ordinated risings on 10 February, the date on which the provincial meetings were to reconvene to receive the reports of their delegates. Bamford later described the Blanketeers' expedition as 'one of the bad schemes which 
accompanied us from London'. If so, however, it had arrived earlier than this. ${ }^{28}$ Joseph Mitchell, Bamford's fellow Lancashire delegate, already had close links with the London radicals. His Address to the People the previous autumn had consisted mainly of a long address to the Prince Regent. It ended with this guarded plan of action in the event of parliament's refusal to reform itself:

You have nothing to do, but to apply firmly - but respectfully, to the King request him to use his prerogatives - and if he should happen to doze a little, as the best of princes may sometimes sleep - you must take care not to forget him, when awake. ${ }^{29}$

Cobbett's Address to Journeymen and Labourers a month later ended by reminding his readers: 'Any man can draw up a petition, and any man can carry it up to London, with instructions to deliver it into trusty hands, to be presented whenever the House shall meet'. ${ }^{30}$

The right to petition developed in the popular imagination. At a meeting in Manchester on 21 January, reported an informer,

The Orator Baguley said they would Petition the Prince, and that in case the Petition was not granted by Parliament, the next step would be to Petition the King. In case they had no Answer at the expiration of Forty Days the People had a Right by Magna Charta to imprison the King and all his Family. ${ }^{31}$

This curious claim, with its invocation of the biblical interval of forty days, puzzled the authorities, as it continues to puzzle historians, but Bagguley repeated it at a crowded weekly meeting in Manchester a fortnight later. Then:

Mr. Benbow arose from the Chair at the close of discussion. He produced acts of Parliament from the reigns of Charles II \& James II. The first was, he read the rights of petitioning, not above 20 in each petition \& not above 10 to carry the petition to present to H.M.The next act was the right of such to say what you must do with them. ${ }^{32}$

The Act of Charles II to which Benbow referred was the 1661 Act Against Tumultuous Petitioning, fashioned at the Restoration to prevent petitioning of parliament in force. The Act had been modified but not entirely superseded by a provision in the Bill of Rights, 'that it is the right of subjects to petition the King, and 
that all commitments and prosecutions for such petitioning are illegal.' Interestingly, this protected petitioners to the throne, but not to parliament. The authorities argued, somewhat shakily, that the 1661 Act still governed the manner of all petitioning to government. Major John Cartwright, the veteran constitutionalist whose slogan was 'hold fast by the laws', advised that the 1661 provisions be observed anyway. Benbow assured his hearers that such petitioning remained an enforceable right: 'You may do this without asking leave of the magistrates; then when there are five hundred thousand men in London will 5 or 6 hundred dare to refuse you?' To guard against the threatened storm on 10 February an immense number of the most respectable inhabitants of Manchester \& the neighbourhood' were sworn in as special constables. The Home Office expected simultaneous mass meetings in London and the provinces and put the military on the alert. ${ }^{33}$ The Oldham and Manchester meetings did indeed reconvene on 10 February to receive formally the results of their petitions to parliament, but everything passed off peaceably. ${ }^{34}$

Around this time, London radicals got hold of and published the long-forgotten manuscript of Robert Southey's play Wat Tyler, written in 1794 in support of the radicals on trial for treason but suppressed by its author. ${ }^{35}$ In the young Southey's version of the peasants' revolt of 1381, the men of Essex attack the collectors of a poll tax imposed to pay for a ruinous war. Crying 'To arms! For Liberty and Justice!' they march on London, encouraged by their leader Wat Tyler:

On, on to Freedom; feel but your own strength,

Be but resolved, and the destructive tyrants

Shall shrink before your vengeance.

At Smithfield Tyler goes forward alone to parley with the King, and this dialogue takes place.

KING. Tyler, why have you kill'd my officer?

And led my honest subjects from their homes,

Thus to rebel against the Lord's anointed?

TYLER. Because they were oppress'd.

KING. Was this the way

To remedy the ill? - you should have tried

By milder means - petition'd at the throne - 
The throne will always listen to petitions.

TYLER. King of England,

Petitioning for pity is most weak,

The sovereign people ought to demand justice....

The hour of retribution is at hand,

And tyrants tremble - mark me, King of England.

As Wat Tyler went on sale in early February, the radical Black Dwarf devoted an issue to the subject of petitioning. 'The right of petition is only the privilege of slaves' it declared, speaking directly to the thousands of disillusioned petitioners:

You may assemble in your parishes, when you can get leave of the rector and churchwardens; in your towns, if the mayor chooses to call a meeting; in a tavern, if you choose to be taunted with the rebuke, that you are not ALL the inhabitants of the town; in the fields, if you wish to be called a mob, and to be surrounded with soldiers ... You may then buy as many skins of parchment as you please, you may indeed; and write your petition out fair, and get all your neighbours to sign it; and then you can take it to a member of parliament, and ask him to present it; which many of them will do for you... [But] . . . if your valuable constitution is injured, or totally destroyed, you must only ask for its renovation in the most mild and gentlemanly terms. The House must not be insulted!

The point was not to petition the Commons humbly but to stand up and remonstrate with the crown.

Was John petitioned to sign Magna Charta: - Was Charles petitioned to lay down his head upon the block: - was James petitioned to abdicate his throne? Or was William petitioned to accept the Bill of Rights? No! no! the right of petitioning with your ancestors meant the right of laying their grievances before the highest authority, and demanding, or ENFORCING an attention to their wrongs... ${ }^{36}$

The next serious step came at an open-air meeting in Manchester on 3 March. William Benbow told a meeting of 6-12,000 people of an imminent march on London. He expected 20,000 to go and warned them that they would face resistance, 
But I am ready to go with you, and will lose every last Drop of Blood in these Veins in the cause of Liberty ... I doubt not you will be Men, stepping forward, like Englishmen, to demand your Rights. A Blacksmith in the Reign of Richard the $2^{\text {nd }}$ went to London with 20,000 men, and got their liberties; which remained till they were destroyed by Tyranny. ${ }^{37}$

Benbow also tried to persuade Bamford that 'the Blanketeers would march to London, thousands in number; and that their petitions would be graciously, if not with some awe, received by the Prince Regent in person.' Bamford remained sceptical, and stood aloof. At another Committee meeting in Manchester, 'Bradbury reverted to the French Revolution shewing how formidable the people were when determined and resolved to be free ... He then adverted to King John being compelled to sign Magna Charta on one knee and that it only required unity and courage in the people to accomplish as great objects now as were done in those days. ${ }^{38}$ On 6 March, John Johnston explained the plan in Manchester:

Gentlemen, if you set out from Manchester in the way proposed, you will not get 3 miles without an attempt to stop you, and if you be surrounded by the Police $\&$ perhaps Soldiers you will be an easy prey if you have nothing but your open hands (long \& significant pause); you may rest assured it will be the case, so look for nothing else. If your leaders can get you through a few towns, you are sure of hosts of recruits. If we could get you as far as Birmingham, the whole would be done, for I have no doubt you will be 100,000 strong. Then

Gentlemen it would amount to an impossibility to bring anything to resist you ... all the large towns are adopting the same plan. ${ }^{39}$

Shortly afterwards Habeas Corpus was suspended and Johnston and other local leaders were either arrested or went underground. The outdoor meeting, as we have seen, they reconvened the following Monday, 10 March, to send a column of 'Blanketeers' to London to petition the Prince Regent. Addressing them as they set off, Samuel Drummond declared, 'We will let them see it is not riot and disturbance we want, it is bread we want and we will apply to our noble Prince as a child would to its Father for bread ... so lawful \& constitutional a proceeding'. ${ }^{40}$ One of the arrested marchers recalled the words: 'They spoke from the stage that we must go to the Prince - We were to beg him as a father to give us bread'. 'They talked that the people must go to London to petition the Prince Regent for a reform for they were starving at home \& could not get bread', said another. 'They said it was lawful', said a 
third, a former 'seaman in His Majesty's service'. Samuel Bamford spoke to some of the marchers afterwards. ${ }^{41}$ "What would you really have done," I said to one of them, "supposing you had got to London?" "Done?" he replied, in surprise at the question; "why iv wee'd nobbo gett'n to Lunnun, we shud ha' tan th'nation, an' sattl't o'th dett." 42

The confused series of attempted risings which followed were each aimed at securing a successful repeat of the Blanketeers' venture. On 11 March a minor Manchester radical named William Lomax was approached by a mysterious man probably a spy - with a plan to 'make a Moscow of Manchester'. Agents sent to canvass the plans in Middleton and Oldham were denounced as spies, but the plan found enough support among the now-leaderless radicals to proceed to two secret delegate meetings in Middleton and nearby Chadderton. ${ }^{43}$ The plan was to set fire to mills and houses in central Manchester in order to draw the troops out of their barracks, seize their stocks of arms, release the imprisoned Blanketeers, and secure a second march to London for long enough to get clear of Manchester and gather support. It was said that 'two or three thousand would be sufficient to do what they had to do, for no doubt they would be fifty thousand strong by Daylight in the morning. ${ }^{44}$ This almost Arthurian belief in hidden armies of rebels, always over the next hill or in the neighbouring valleys, was one of the tropes of the age, and may have owed something to the Luddite experience of a few years earlier. ${ }^{45}$

Meanwhile, in London, part of Southey's Wat Tyler was read on 23 March 1817 at one of the regular gatherings of the London radicals at the Mulberry Tree tavern. ${ }^{46}$ Extensive extracts appeared in the issues of Wooler's Black Dwarf and Sherwin's Republican published a few days later, on the very weekend appointed for the Manchester rising. ${ }^{47}$ Sherwin's introduction declared that Wat Tyler's rebellion had 'a distinguished place' in history: 'The Nation, even at that distant period, had began [sic] to rise above the barbarous state into which the conquest, by William the Norman, had plunged it.' It also warned readers of the fate of Wat Tyler, treacherously murdered by the Mayor of London after dropping his guard while dealing with the King.

The authorities knew every detail of the conspiracy as it happened, for their own agents were at its heart. On Friday 28 March the conspirators were arrested in Manchester as they discussed their final preparations, and after a weekend of arrests and alarms all was over. Joseph Mitchell at this time was in London, by his own account sheltering from the authorities after the march of the Blanketeers but probably also preparing the London radicals to receive their Lancashire colleagues at the second attempt. Oliver the Spy then managed to gain Mitchell's confidence and 
accompanied him on a tour of the midland and northern manufacturing districts, setting in train the chain of events which led to the abortive risings of 9 June at Pentridge near Sheffield and at Folley Hall near Huddersfield.

The sense of hidden potential, of working people organising underground without leaders, has lent an air of fascination to these subsequent risings; in fact they were a good deal less mysterious to the authorities than the more open mass movement that preceded them. Conceived in defeat, promoted by espionage and founded on fantasy, their failure was unsurprising, but they drew their power from the earlier petitioning campaign. The abortive 'march of the Blanketeers', was an attempt by the massed radicals of the Manchester region to march to London to appeal in the last resort to the crown over the head of parliament, and to exercise in person the right of petitioning which had been denied them by proxy. Why was the prospect of a successful mass march on London so credible to so many people?

In late Hanoverian Britain there was no model of peaceful, incremental political change. Neither the reformers nor the authorities could know that the events of 1817 would be followed by incremental extensions of the franchise in 1832, 1867, 1884-5, 1918 and 1928. The available models were all of sudden change. Public meetings were reminded of Magna Carta in 1215, the peasants' revolt of 1381, the great rebellion of 1642, the Glorious Revolution of 1688-9, and the storming of the Bastile in 1789. The tradition of petitioning the throne (as distinct from petitioning parliament) went back a long way. ${ }^{48}$ Tumultuously exercised in the rebellions of 1381,1450 and 1549 , collective petitioning had established itself in the sixteenth century as an important form of political activity whose legitimacy could not be denied however much it worried government. ${ }^{49}$ The Grand Remonstrance of 1641 had been a final warning to the throne which set out the grounds for resistance, and had succeeded in forcing a temporary settlement between crown and parliament. Petitioning at this level was not an alternative to rebellion but an essential stage in establishing the right to rebel - not the first resort, as it has become in the democratic age, but one of the last.

Whig contract theory of government depended upon occasional renewals of the contract, but writers were circumspect about how this might legitimately come about. The issue of whether James II was actually overthrown in 1688 had been finessed at the time and fudged thereafter. But whatever the significance of the Glorious Revolution, the Hanoverian regime had been founded in 1714 not so much on the assertion of the Whig right to resistance but on the denial of the Jacobite right to rebel. It was the authorities who tended to remind the public of the regicides of 1649 
and 1793 as dark examples of the true ends of rebellion, while radicals preferred happier precedents. 'Baguley is well vers'd in the history of his Country, \& has the consummate art to pervert and torture it to his own purposes', complained a Manchester magistrate. 'The Resistance of the Barons to King John's Tyranny was applied in this way with the desired effect' ${ }^{50}$ In 1818 John Johnston, one of the Blanketeers' leaders, addressed a meeting of striking weavers near Middleton:

Just have the Spirit of our Forefathers \& pull altogether as they did in the year 1213 at runummede [Runnymede], do as they did take your Petition in one hand \& a sword drawn in the other \& demand ye compel them to give up those rights \& libertys that belongs to English men ... the annals of HISTORY tells us what a Tyrant James the second was... and so the people conquered without the loss of a single man how was this because they were unanimous and determined to put down Tyrannism. ${ }^{51}$

The more moderate Samuel Bamford concluded an open-air lecture on English parliamentary history with this rallying call:

England is not that happy island we are told through the annals of History that it was used to be. The people have now \& then met with a Tyrant but they were unanimous ... Now if you were all as your fore father[s] were Unanimous and resolute what would become of Tyrannism \& Despotism . . . never say you are English Men if you suffer this any longer. ${ }^{52}$

The constitutional idiom was also an idiom of rebellion. ${ }^{53}$

Steve Poole in his book The Politics of Regicide has demonstrated that there was a widespread belief in the right of last resort to appeal to the monarch in person. This right was associated with the Whig contract theory of monarchy, which had been developed to defend the Glorious Revolution and the Hanoverian succession. ${ }^{54}$ Several supposed assassins of George III were in fact frustrated petitioners who had somehow breached the barriers of protocol to make a despairing plea to the king in person. Petitioning the throne may have gained in legitimacy in the war years as the monarchy of George III sought successfully to put itself above party, adopting the Jacobite oak branch and embracing the old Jacobite 'patriot king' principle. ${ }^{55}$

The prime minister William Pitt has usually been identified as a Tory and Pitt's great opponent Charles James Fox as a Whig. In the latest volume in the Oxford History of England series, Boyd Hilton suggests that one might equally see Pitt as the 
Whig and Fox as the Tory. Fox opposed the court in the name of the people from a seat - Westminster - notable as a former citadel of Jacobite opposition to Walpole. He did so in alliance with an alternative candidate for the throne - the Prince of Wales - on whose behalf as Prince Regent Fox claimed full and undivided royal powers. 'Fox's instinctive populism and hostility to an oligarchic court were worthy of his Jacobite forenames,' writes Hilton. ${ }^{56}$

The tendency of contemporaries to get muddled up between Jacobites and Jacobins was more than just a Freudian slip. Paul Monod has argued that Jacobitism was not merely a dynastic cause but 'a morality play whose central theme was the perversion of justice by usurped power' and 'the last great effort to preserve a traditional political culture which united the elite and the common people'. Jacobitism may have died as serious politics in the mid-eighteenth century, but it connected with a deep-rooted, festive and theatrical political culture which was renovated by the Wilkites and passed on to future radical movements. ${ }^{57}$ In Nicholas Rogers' phrase, Jacobitism provided 'an idiom of defiance'. ${ }^{58}$ The French and Napoleonic wars saw battles over the meaning of patriotism, over the political status of urban communities, and over the right to festivity, paralleling the battle over the constitution. ${ }^{59}$ The fall of Napoleon saw a chorus of radical writing endorsing, a little too loudly for comfort, the government's satisfaction at the fate of a tyrant at the hands of lovers of true liberty. ${ }^{60}$ In the aftermath of the 'bread or blood' riots of the spring of 1816 a curious episode of petitioning occurred. Parties of colliers and forgemen from the west midlands set out for London, collecting money and 'dragging after them Waggons filled with Coals, decorated with Flags, and covered with inflammatory Inscriptions, with the professed Intention of presenting the same to His Royal Highness the Prince Regent, and of Petitioning His Royal Highness at the same time to relieve them from certain grievances and distresses'. As they approached the capital, Sidmouth, the home secretary, sent out agents to intercept them and explain 'that altho' Individuals having Grievances to complain of, are permitted to Petition the Throne for Redress, the mode of doing so which they are pursuing is unconstitutional and illegal, that it cannot and will not be suffered'. The petitioners turned out to be 'not at all disposed to turbulence or misbehaviour of any kind'; some indeed had set out with the blessing of local land stewards and magistrates. Tired out after their long haul, they were satisfied to be paid off with money and the promise of sympathetic attention to their grievances. ${ }^{61}$

How serious were the marchers of 1817 in their appeal to the throne? The London-based republican promoters of the strategy of forceful remonstration, like the editors Wooler and Sherwin, seem to have expected that it would fail, leaving a mass 
of outraged petitioners far from home and open to new leadership. It is also true that melodramatic postures, combining extravagant claims of legitimacy with dire threats of disaster, were part of the political currency of the age. We should not take melodrama too seriously. ${ }^{62}$ More explicit language was however used when the leadership thought no-one else was listening. The Manchester secret committee sat all night on 30 January 1817 to debate parliament's rejection of the reform petitions, vowing (according to one informant) that 'they wou'd never desist 'till he (the Prince Regent) has shar'd the fate of Charles the $1^{\text {st }}$. This, my Lord, is an event to which the party constantly refer'. But this was not necessarily a typical occasion; it was the anniversary of the execution of Charles I, still marked by official public prayers, so some reference to it was only natural. ${ }^{63}$

Republican leaders could not carry their followers all the way on the monarchy. The same issue of The Republican which published extracts from Southey's Wat Tyler proclaimed that as its title put many readers off it would henceforth become Sherwin's Weekly Political Register. With rebellion imminent in Manchester this move was certainly prudent, and with William Cobbett having recently fled to America it was a shrewd move to grab his journal's title. But it is also worth noting that the radical strategy at this point required the intervention of the monarchy and the use of the royal prerogative, not their abolition. The memory of the Prince Regent's former association with the Foxite Whigs may have encouraged the belief that the future George IV might at least know when to bow to overwhelming popular pressure. Examples of successful rebellions from the past were more than just a useful pretext for insurrection; they offered an essential counterconstitutionalism to that of loyalism.

This perspective also helps to make sense of the Queen Caroline affair which blew up in 1820, after any remaining illusions about the Prince Regent were dispelled by his congratulations to the authorities after Peterloo. At a time when the Six Acts had recently banned all the main forms of popular political activity, the Queen Caroline affair offered another opportunity to restore the constitution through the agency of the monarchy by using the estranged Queen to 'storm the closet' on behalf not of an opposition faction but of the whole people. This was not necessarily an attack on the institution of monarchy any more than attacks on politicians were attacks on the institution of parliament. In a sense the Queen Caroline affair was the last hurrah of Jacobitism. ${ }^{64}$

Chartism grappled with many of the same constitutional issues, although, with a more coherent national movement to co-ordinate and a more responsive parliamentary process to exhaust, the process took rather longer to unfold. The 
events of 1839 followed a recognisably similar cycle to those of 1817 . The gathering of signatures in the winter of 1838-9 was followed by the National Convention, the presentation of what O'Connor promised was 'the last petition', the retreat to the provinces to regroup, the final remonstrance backed up by ulterior measures in the form of the 'sacred month', and finally (in Newport in November) open rebellion. ${ }^{65}$ In May 1839 , as in early 1817 , the centre of activity passed rapidly from London to the provinces as the Convention transferred to Birmingham and was supported by meetings in other cities, Manchester among them. William Benbow, promoter of the 'Grand National Holiday', was a former colleague of Mitchell and a veteran of the failed Manchester risings of 1817. Echoing the sentiments of 1817, the Birmingham Chartist John Fussell asked: 'Did the men who met John at Runnymede obtain their charter by moral power? No.'66

It is important to appreciate the relationship between the petitioning strategy and the Chartist Convention. James Epstein has shown how the Convention was careful to legitimate itself with reference not to the events of the French revolution but to the historic English 'Conventions', the quasi-parliaments which had brought about both the Restoration of 1660 and the Glorious Revolution of 1688-9, and then retrospectively legitimated themselves through the authority of the new monarch. Conventions had again been mooted by reformers in 1819 and 1832. But there was also the problem of the sedition legislation of 1792-1820 which remained in force, ironically given greater legitimacy by the slightly more democratic constitution under which it now operated. As one delegate bitterly explained, 'they sat under the cloak of being a petitioning body . . . because petitioning was almost the only constitutional right they had left'. ${ }^{67}$ In order to navigate around the seditious meetings' legislation the National Convention (or 'General Convention' as it was carefully designated) was notionally composed of a maximum of forty-nine delegates, each elected at an open public meeting to represent a particular locality. It was emphatically not an association of societies or interest groups, which would have been both inconclusive and illegal, but an alliance of petitioning localities, collectively representing the people as a whole. ${ }^{68}$

Signing a petition was almost the only legal way that non-electors (women included) could assert a voice in the political process, not merely as private individuals but as members of communities with legitimate interests at stake. In the later eighteenth century petitioning had become, at the single issue level, an important mode of political mobilisation, taking off in the 1780s with the anti-slavery movement. In the case of the franchise the relevant interest group was the entire community or locality, and this was how the Chartists organised. As Pickering has 
explained in an important article, leading Chartists understood that petitioning was a 'constitutional ... reason for bringing the people together', a right which 'legalizes our meetings, and gives assurances of safety'. Like the mass platform rallies of 1819 (some of which moved illegally to elect their own MPs or 'legislatorial attorneys') the petitions of 1839, 1842 and 1848 presented an alliance of communities, assembled either physically or symbolically to demonstrate their citizenship and claim their political rights. This was why it was so important for the petition to be paraded through the streets of the capital and forced through the doors of parliament. ${ }^{69}$ In the spring of 1839 , as Chartists faced the immediate prospect of the National Petition's rejection by the House of Commons, attention (as in 1817) began to shift from parliament to the crown. Pickering notes how the republican Bronterre O'Brien, conceding that the monarchy remained popular, issued a series of letters 'designed to put the Queen on notice'. He predicted that 'the people having petitioned their representatives in vain, they will then turn to your Majesty'. A Liverpool Chartist urged Prince Albert to become 'the People's Champion ... like Alfred'. The London Working Men's Association urged Victoria to put herself beyond faction and order her ministers to draw up a bill for adult suffrage, and in Newcastle Robert Lowery promised the Queen that if she did so 'there was one million armed men ready to protect her and the Charter'. ${ }^{70}$ In making their pitch to the crown, Chartist leaders had before them the precedent of the royal retreat over Catholic Emancipation in 1829, and the forcing through of the 1832 Reform Bill by the use of the royal prerogative, both in the context of serious popular disorder. Then, with the Chartist National Convention sitting and the Whigs temporarily unable to form a government, the 'bedchamber plot' kept Peel and the Tories out of power, indicating that there was still some political potential left in a throne occupied by a young 'Queen of the Whigs'. ${ }^{71}$

Such hopes were disappointed, but a year later Chartists had cause to thank 'the mercyfull Queen of Old England' when a mass petition requesting a reprieve for the Newport rebels was successful. ${ }^{72}$ This was an encouraging contrast to the Prince Regent's behaviour after Peterloo. When the second National Petition was rejected in 1842 the Chartist Convention adopted a memorial to the Queen. The same cycle was repeated in April 1848, when at the third Convention Ernest Jones urged simultaneous mass petitioning of the Queen over the head of parliament and sought to assemble 200,000 petitioners in London in a scenario of (in Miles Taylor's phrase) 'flags, soldiers, mobs and monarchs'. ${ }^{73}$ Victoria's advisers were blamed for coming between the monarch and her people, and O'Connor declared that he had always been 'for a monarchy, subject to that power behind the Throne - the people'. ${ }^{74}$ 
Once again there is room to argue that there was a certain amount of opportunism about these appeals to the throne, but the roots of popular monarchism went deep. Surveying 'the republic of Britain', Frank Prochaska, following Linda Colley and Marilyn Morris, emphasises the resurgence of the monarchy during the wars against France. The throne was flooded with petitions as 'constitutional reformers and loyalists alike looked to the King as a final court of appeal'. Even George IV could not sink the crown, for his hostile subjects persisted in distinguishing between the throne and its occupant; his failures assisted the development of constitutional monarchy. After 1832, 'virtually all radicals now assumed that their principal enemy was the oligarchy not the Crown'. ${ }^{75}$ Paul Pickering has argued that genuine republicanism was marginal in the Chartist movement. 'The majority of Chartists ... were not roundheads', and hostility to aristocratic privilege did not generally extend to Britain's 'mild monarchy'. During the 1830 s radical fire was concentrated on parliament, and when attention moved to the monarchy in 1839 it was as a source of hope rather than of corruption. Brian Worrall's survey of some two hundred nineteenth-century working-class autodidacts found only two identifiable republicans. ${ }^{76}$

Radical disillusionment with parliament was as strong as disillusionment with the crown; the demand for representation was also a demand for leadership. Surveying the uproar in the House of Commons from the public gallery during the debates on the reform petitions of January 1817, Samuel Bamford mused: 'O! for the stamp of stern old Oliver on this floor; and the clank of his scabbard, and the rush of his iron-armed band, and his voice to arise above this babel howl - "Take away that bauble"- "Begone; give place to honester men". ${ }^{77}$ Napoleon and Cromwell were both widely idealised as strong popular leaders who had swept away corrupt political establishments. ${ }^{78}$ At different times, Queen Caroline, Henry Hunt and Feargus O'Connor were looked to for a similar role. Belchem and Epstein have examined the propensity of the reform movement to throw up 'gentlemanly radicals', charismatic popular leaders like Hunt and O'Connor, a phenomenon which was partly explained by the illegality of formal political organisations. As E. P. Thompson noticed, 'the reform movement might use the rhetoric of equality, but many of the old responses of deference were there among the huzzaing crowd' ${ }^{79}$ Feargus O'Connor and Ernest Jones both traded effectively on their supposed blue blood. O'Connor, through his father, claimed to be descended from the kings of Ireland. Part of the appeal of his famous fustian jacket, adopted later in his career, was that its wearer was no ordinary man but 'Feargus Rex by the Grace of the People' (as he once ironically styled himself). ${ }^{80}$ Jones, identified by Miles Taylor as a 'social renegade', made much of his 
aristocratic and royal connections; his early political ideas were 'focused around the idea of a patriot king, sweeping away faction and earning the love of his people'. ${ }^{2}$

Luddism can also be understood in terms of an unfulfilled popular desire for leadership, as Katrina Navickas has shown. 'General Ludd' was one in a long line of mythologised leaders, somewhere between regional heroes such as 'Bob Cranky' and 'Jone o' Grinfilt' and national figures such as Wat Tyler, John Bull and Admiral Nelson. 'General Ludd was imagined', argues Navickas, 'because the increasingly radical-leaning general population was searching for a leader. In 1812 they were unable to find one locally or were unable to raise one themselves because of magistrate repression. ${ }^{82}$ Ned Ludd was the creation of a society which had been forcibly polarised in the 1790s and then mobilised in its own defence for the next twenty years, and which was (as Stuart Semmel puts it) 'royalist without being loyalist'. ${ }^{83}$

1819, the year of Peterloo, was also the year of Ivanhoe, Walter Scott's reworking of the Robin Hood legend with its influential tale of resurgent Saxon chivalry. In the Chartist period, Disraeli's 'two nations' were only superficially 'the rich and the poor'. Sybil is essentially a tale of Saxons and Normans, and the mysterious popular leader, Walter Gerard, is a Robin Hood-like character who turns out to have blue blood and who heals social divisions by marrying his daughter Sybil into the ruling Norman elite. The figure of Wat Tyler, the loyal rebel who faced down a king, retained its popularity in this period. His name was adopted by individual Chartists and displayed on Chartist banners, and a Wat Tyler brigade of Chartists was established in Greenwich, just down the road from Blackheath where rebels of 1381 had assembled. In a play of 1849 Wat Tyler was celebrated as 'the great and original Chartist'. ${ }^{84}$ Tales of alternative leaders carrying their own legitimate authority through a mixture of blood and popular acclaim had obvious appeal for radicals seeking to challenge the loyalist monopoly on constitutionalism and patriotism. The age of reform was characterised by this kind of Robin Hood republicanism.

The main features of radicalism in the first half of the nineteenth century were broadly consistent: constitutionalism, petitioning, the strategy of the national convention, a search for leadership, and a latent monarchism, all informed by a melodramatic sense of final confrontation. Like Jacobites, Wilkites and food rioters before them, later radicals sought to deploy a potent mixture of constitutional legitimacy and overwhelming numbers against erring authorities. Between petitioning and open rebellion there lay a stage which has often been overlooked: the 
remonstrance, the appeal to the crown, putting the sovereign authority on final notice whilst ostentatiously rallying one's forces. The march of the Blanketeers on London in 1817 , the abortive risings that followed it, the mass rallies of citizens in 1819 , the 'sacred month', and indeed the People's Charter itself, were all designed as irresistible reminders of the popular foundations of sovereignty, intended to bring about the effects of rebellion without the need for actual armed force.

The problem in both periods was not whether to choose persuasion or force, peace or war - the dilemma insisted upon by authorities everywhere - but how to bring to bear the full force of popular commitment whilst avoiding the risk of open rebellion. Radical strategies were all solutions to this problem - not of how to outfight those in power but of how to make them give in. The monarch would have his Cauecescu moment, London its velvet revolution. In the debate over popular sovereignty there has been too much emphasis on the 'popular' and not enough on the 'sovereignty'. If popular sovereignty was the ideal, parliament the problem, and the constitution the prize, then it made sense for the people to try and recapture the throne.

Differing versions of this paper were given at the London Socialist Historians Group conference on E. P. Thompson: The Freeborn Englishman, Institute of Historical Research, 2003; the Collective Memory and the Uses of the Past conference at the University of East Anglia, 2006; the Leeds University eighteenth-century seminar, 2007; the University of Oxford Re-imagining Democracy colloquium, 2007; and the Society for the Study of Labour History Chartism Day, Sheffield, 2007. I am grateful to all those involved for the opportunity and for the discussions, particularly to Dorothy Thompson and to the organisers: Keith Flett, Andy Wood, Malcolm Chase, Mark Philp, Joanna Innes, Joan Allen and Owen Ashton. Needless to say, none of these is responsible for the result.

${ }^{1}$ The National Archives, Home Office Papers, HO40/5 (Manchester Papers), No. 11, reprinted in H. W. C. Davis, 'Lancashire Reformers' (Manchester: Manchester University Press, 1926), Appendix, item 29. (Reprinted from the Bulletin of the John Rylands Library 10, 1, January 1926).

${ }^{2}$ E. P. Thompson, The Making of the English Working Class (London: Penguin, 1968), p. 660 and ch. 15 passim.

${ }^{3}$ Thompson, Making of the English Working Class, pp. 733, 712.

${ }^{4}$ On 1819, see: Iorwerth Prothero, Artisans and Politics in Early Nineteenth-Century London (Folkestone: Dawson, 1979), ch. 6; James Epstein, 'Understanding the Cap of Liberty: Symbolic Practice and Social Conflict in Early Nineteenth-Century 
England', Past and Present, 122 (Feb. 1989), reprinted with related essays in his Radical Expression (Oxford: Oxford University Press, 1994); Anna Clark, The Struggle for the Breeches Berkeley, Los Angeles and London: University of California Press, 1995); Robert Poole, "'By the law or the sword": Peterloo revisited', History, April 2006, 254-76, and 'The march to Peterloo: politics and festivity in late Georgian England', Past and Present, 192 (August 2006), 109-153.

${ }^{5}$ John Foster, Class Struggle in the Industrial Revolution (London: Weidenfield \& Nicholson,1974), pp. 143, 140-9, 3-7.

${ }^{6}$ Michael Winstanley, 'Oldham Radicalism and the Origins of Popular Liberalism, 1830-52,' Historical Journal, 36, 3 (1993), 619-43.

${ }^{7}$ Gareth Stedman Jones, 'Class struggle in the industrial revolution' and 'Rethinking Chartism', both in his Languages of Class (Cambridge: Cambridge University Press, 1983). The former appeared first in 1975 , and the second as a seminar paper in 1977, appearing in print as 'The Language of Chartism' in The Chartist Experience, ed. by James Epstein and Dorothy Thompson (London: Macmillan, 1982), 3-58. ${ }^{8}$ John Belchem, 'Orator' Hunt: Henry Hunt and English Working-class Radicalism (Oxford: Oxford University Press, 1985), pp. 3, 6, 74-6. On the London radical culture of 1817 years, see lan McCalman, Radical Underworld: Prophets, Radicals and Pornographers in London, 1795-1840 (Cambridge: Cambridge University Press, 1988), and David Worrall, Theatric Revolution: Drama, Censorship and Romantic Period Subcultures 1773-1832 (Oxford: Oxford University Press, 2006).

${ }^{9}$ Proceedings of the Middleton Union Society . . . 19 October 1816, The National Archives (TNA) TS/24/3/75.

${ }^{10} \mathrm{HO} 42 / 153$, fol. 385, William Fitton to John Kay, 3 September 1816; HO42/153, fol. 371, Chippendale to Fletcher, 4 September 1816; 'Documents Concerning the Formation of Hampden Clubs 1816-17', Manchester Central Library (MCL), MS f.363.D1. 
${ }^{11}$ A Report of the Proceedings of the Public Meeting held in . . Manchester . . Oct. $28^{\text {th }}, 1816$ (Manchester, 1816), TNA TS 24/3 71. This, and the report of the Middleton meeting cited in fn. 9 above, were purchased by agents at the office of the radical Manchester printer James Molineux on the day of the Blanketeers' march and held as evidence.

12 Joseph Mitchell, Address to the People, enclosed with Chippendale to Becket 7 Oct. 1816, HO42/153, fols 374-82.

${ }^{13}$ Belchem, Orator Hunt, p. 53; 'Documents Concerning the Formation of Hampden Clubs 1816-17', Manchester Central Library (MCL), MS f.363.D1; HO40/3, Part 2, fols 784-7, John Kay to John Knight, 21 Nov. 1816; Proceedings of the Hampden Club (n.d.), British Library, 8135.f.19, 2 November 1816. The Club's previous annual meeting had been attended by only two people, but it had then revived its own fortunes by abolishing the property qualification for membership and replacing it with election by ballot: Its success lasted only a few months and five years later it had still not paid its printing debts: Proceedings, circulars of June 1816 and 1822.

${ }^{14}$ Thompson, The Making of the English Working Class, p. 705; Joseph Mitchell, The Blanketteer, 23 October 1819.

${ }^{15}$ Prothero, Artisans and Politics in Early Nineteenth-century London, ch. 6; HO40/3, Part 1, fol. 722, Chippendale to Fletcher, 12 December 1816 (reproduced in part in Davis, Lancashire Reformers, Appendix, item 19.

${ }^{16} \mathrm{HO} 40 / 4 / 1$, (2) fol. 42, Chippendale to Fletcher, 3 December 1816, cited in Chase, People's Farm, p. 98, also in HO40/3, Part 1, fol. 719; HO40/3, Part 1, fol. 702 Chippendale to Byng, Oldham, 7 December 1816, partly reproduced in H. W. C. Davis, Lancashire Reformers, Appendix, item 16.

${ }^{17} \mathrm{HO} 40 / 9 / 4$, fols 440-1. Axson to Nadin, report of Meeting at Bibby's large room, Manchester, 9 December 1816. 
${ }^{18} \mathrm{HO} 40 / 10$, fol. 113 , report from the spies Hall and Rose to Nadin; HO42/156, fol. 100 for the requisition; Thompson, The Making of the English Working Class, pp. $674-8$.

${ }^{19} \mathrm{HO} 40 / 3$, Part 5, fol. 944.

${ }^{20} \mathrm{HO} 42 / 157$, fol. 182; also HO42/156, fol. 36.

${ }^{21}$ There are several reports of this meeting in the Home Office papers, which was attended by at least two informers: HO40.9, Part 4, fols 434-5; HO40/3, Part 1, fol. 756; HO40/10, part 2, fol. 115; HO 40/3 Part 2, fols 805-9. The last of these is reproduced in part in Davis, Lancashire Reformers, Appendix, item 20.

${ }^{22}$ HO40/3, Part 2, fol. 805, Chippendale to Fletcher, 19 December 1816.

${ }^{23}$ To the People of England (Manchester, 1816), Manchester Central Library (MCL) P3246; HO42/157, fols 160-1.

${ }^{24}$ Manchester Political Register, 4 January 1817.

${ }^{25} \mathrm{HO} 40 / 3$, Part 1, fol. 732, agent $\mathrm{XY}$ to Fletcher, 15 January 1817 (also in HO42/158, fols 126-7).

${ }^{26}$ Robert Huish, History of Henry Hunt (1836), pp. ii, 26-42; Cobbett's Weekly Political Pamphlet, 22 February 1817; Manchester Political Register, 1 February 1817; Samuel Bamford, Passages in the Life of a Radical (1839-41: 1844 edn, reprinted London: Cass, 1967 ed. W. H. Chaloner, 1967), ch. 6.

${ }^{27}$ Manchester Courier, 1 Feb 1817; Manchester Political Register, 15 February 1817, 1 March 1817; Olivia Smith, The Politics of Language 1791-1819 (Oxford: Oxford University Press, 1984), ch. 5.

${ }^{28}$ Bamford, Passages, ch. 6.

${ }^{29}$ Mitchell, Address to the People, 14. At this point Mitchell slips implicitly from addressing the MPs to addressing the people.

${ }^{30}$ Cobbett's Political Register, 3 November, 1816; Thompson, Making of the English Working Class, pp. 675. 
${ }^{31} \mathrm{HO} 40 / 3$, Part 1, fol. 764. Information of P. C. of Manchester 28 Jan 1817 re Manchester meeting 21 January 1817.

${ }^{32}$ HO40/4 (Supplementary Papers), No. 12. Report of a debate of the Manchester Constitutional Society 3 February 1817, partly reproduced in Davis, Appendix, item 25.

${ }^{33} \mathrm{HO} 40 / 3$, Part 1, fol. 767, Ethelston to Sidmouth, 1 February 1817; HO41/2, fol. 273 Addington to Byng, 8 February. 1817.

${ }^{34} \mathrm{HO} 42 / 159$, fols 28, 35; HO40/10, Part 2, fols 89-90, 132; Manchester Political Register ,15 February 1817.

${ }^{35}$ Frank Taliaferro Hoadley, 'The controversy over Southey's Wat Tyler', Studies in Philology xxxviii (1941), 81-96; David M. Craig, Robert Southey and Romantic Apostasy: Political Argument in Britain 1780-1840 (Woodbridge: Boydell \& Brewer, 2007), pp.1-4; W. A. Speck, Robert Southey: Entire Man of Letters (New Haven and London: Yale University Press, 2006), pp. 51-2, 169-74. Southey also had an essay on 'The Rise and Progress of Popular Disaffection' in the January 1817 Quarterly Review, but this appeared much later in the year.

${ }^{36}$ Black Dwarf , 12 February 1817.

${ }^{37} \mathrm{HO} 40 / 5$, Part 4a, fols $1323 \mathrm{ff}$.

${ }^{38} \mathrm{HO} 42 / 164$, fol 256.

${ }^{39} \mathrm{HO} 40 / 5$, Part 4a, fols 1338-45. (Deposition of John Livsey taken before Mr. Ethelston, 7 March 1817), in Davis, Appendix, item 27.

${ }^{40} \mathrm{HO} 40 / 5$, Manchester Papers No. 11, reproduced in Davis, Appendix, Item 29. ${ }^{41} \mathrm{HO} 44 / 3$, Item 188, depositions of arrested Blanketeers. In their statements the marchers naturally exaggerate their own naivety and lack of involvement with others, but the sense of basic legitimacy is they convey is consistent.

${ }^{42}$ Bamford, Passages, ch. 6.

${ }^{43}$ HO42/164, fols 193-6, deposition of William Lomax; Bamford, Passages, ch. 6. 
${ }^{44} \mathrm{HO} 40 / 5$, Part 4a, Item 29, fol. 1400, Report from Manchester 23 March 1817, partly reproduced in Davis, Appendix, Item 31.

${ }^{45}$ Katrina Navickas, 'The search for "General Ludd": the mythology of Luddism', Social History 30, 3 (August 2005), 281-95.

${ }^{46} \mathrm{HO} 42 / 162$, cited in A. Aspinall, Politics and the Press 1780-1850 (1949; Brighton: Harvester, 1973), p. 46n.

${ }^{47}$ The paper attracted the instant attention of the authorities; there is a copy in HO42/163, fols 461-70.

${ }^{48}$ On petitioning parliament, see Paul Pickering, "'And Your Petitioners \&c": Chartist Petitioning in Popular Politics 1838-48', English Historical Review (April 2001), 36888.

${ }^{49}$ Richard Hoyle, 'Petitioning as popular politics in early sixteenth-century England', Historical Research 190 (November 2002); Andy Wood, Riot, Rebellion and Popular Politics in Early Modern England (London: Palgrave, 2002).

${ }^{50}$ HO42/159, fols 63-4, Ethelston to Sidmouth, 5 February 1817.

${ }^{51}$ HO42/178, fols 314-19.

${ }^{52} \mathrm{HO} 42 / 178$, fol 320-3, Report by Livesey of meeting at Heywood 6 July 1818.

53 James Epstein, 'The Constitutional Idiom: Radical Reasoning, Rhetoric and Action in Early Nineteenth-Century England', Journal of Social History 23, 1 (1990), 553-74. See also Robert G. Hall, 'Creating a People's History: Political Identity and History in Chartism, 1832-1848', in The Chartist Legacy, ed. by Owen Ashton, Robert Fyson \& Stephen Roberts, (Woodbridge: Merlin, 1999), 232-54.

${ }^{54}$ Steve Poole, The Politics of Regicide in England, 1760-1850 (Manchester: Manchester University Press, 2000).

${ }^{55}$ Marilyn Morris, The British Monarchy and the French Revolution (New Haven and London: Yale University Press, 1998); Linda Colley, 'The Apotheosis of George III: 
Loyalty, Royalty and the British Nation 1760-1820,' Past and Present, 102 (1984), 94-129.

${ }^{56}$ Boyd Hilton, A Mad, Bad and Dangerous People? England 1783-1846 (Oxford: Oxford University Press, 2006), pp. 49-50.

${ }^{57}$ Paul Monod, 'Pierre's White Hat: Theatre, Jacobitism and Popular Protest in London, 1689-1760', in By Force or Default? The Revolution of 1688-1689, ed. by Eveline Cruickshanks, (Edinburgh: John Donaldson, 1989), pp. 174-5, 180-1 and passim.

${ }^{58}$ Nicholas Rogers, Crowds, Culture and Politics in Georgian Britain (Oxford: Oxford University Press, 1998), pp. 18 and ch. 1.

${ }^{59}$ Poole, 'March to Peterloo', p?

${ }^{60}$ Stuart Semmel, Napoleon and the British (New Haven and London: Yale University Press, 2004), ch. 6 . Semmel makes the point that both constitutionalist and Paineite radicals could make awkward use of this line of argument.

${ }^{61}$ HO33/1, passim; HO41/1 p. 183, Beckett to Conant et. al., 3 July 1816; Elie Halevy, The Liberal Awakening 1815-1830 (1949), p. 10; Jonathan Fulcher, 'The English People and their Constitution after Waterloo: parliamentary reform, 18151817', in Re-reading the Constitution, ed. by James Vernon (Cambridge: Cambridge University Press, 1996), p. 65.

${ }^{62}$ Or perhaps we should. See Rohan McWilliam, 'The mysteries of G.W.M. Reynolds: radicalism and melodrama in Victorian Britain', in Living and Learning: essays in honour of J.F.C. Harrison, ed. by Malcolm Chase and lan Dyck, (Aldershot: Scolar, 1996), 82-98; R. Poole, 'Melodrama and politics in late Georgian England', unpublished paper delivered to Leeds $18^{\text {th }}$-century seminar, 2007.

${ }^{63} \mathrm{HO} 42 / 158$, fol. 93. Ethelston to Sidmouth, 1 February 1817.

${ }^{64}$ Poole, 'March to Peterloo', 141-3.

${ }^{65}$ Dorothy Thompson, The Chartists (Hounslow: Temple Smith, 1984), ch. 3. 
${ }^{66}$ Malcolm Chase, Chartism: a New History (Manchester: Manchester University Press, 2007), pp. 76-7; Jonathan Fulcher, 'The English People and their Constitution after Waterloo: parliamentary reform, 1815-1817', in Re-Reading the Constitution ed. by Vernon, 52-82; Fulcher, 'Contests over Constitutionalism: the Faltering of Reform in England, 1816-24' (unpublished doctoral thesis, University of Cambridge, 1993), especially ch. 3 .

${ }^{67}$ Epstein, 'The Constitutional Idiom', 561-3. The delegate was Matthew Fletcher. ${ }^{68}$ Epstein, 'The Constitutional Idiom', 563; Chase, Chartism, pp. 35, 58.

${ }^{69}$ Pickering, 'Chartist Petitioning', 374-5 and passim; Poole, 'March to Peterloo'. ${ }^{70}$ Thompson, The Chartists, p. 58; Paul A. Pickering, "'The Hearts of the Millions": Chartism and popular monarchism in the 1840s', History (2003), 240-7. Compare with Antony Taylor, 'Down With the Crown': British Anti-monarchism and Debates about Royalty since 1790 (London: Reaktion, 1999), which implicitly adopts a broad definition of republicanism than that adopted here. Patrick Collinson has argued that the Elizabethan republican tradition was quite compatible with monarchy: Patrick Collinson, 'The Monarchical Republic of Queen Elizabeth I', in his Elizabethan Essays (London: Hambledon, 1994).

${ }^{71}$ Chase, Chartism, pp. 72-3; Dorothy Thompson, Queen Victoria: Gender and Power (London: Virago, 1990), pp. 29-30, 41.

${ }^{72}$ Pickering, 'The Hearts of the Millions', 247.

${ }^{73}$ Miles Taylor, Ernest Jones, Chartism and the Romance of Politics, 1819-1869 (Oxford: Oxford University Press, 2003), pp. 107-11.

${ }^{74}$ Pickering, 'The Hearts of the Millions', 246-8; Chase, Chartism, pp. 304, 314-15.

${ }^{75}$ Frank Prochaska, The Republic of Britain 1760-2000 (London: Allen Lane, 2000), pp. 30-1, 47-8, 62; Colley, 'Apotheosis of George III'; Morris, The British Monarchy and the French Revolution. 
${ }^{76}$ Pickering, 'The Hearts of the millions', 233, 243; Thompson, Queen Victoria; Brian Worrall, 'Self-taught working men: the culture and ideology of autodidacticism, with special reference to Lancashire, c. 1790-1830' (unpublished doctoral thesis, Manchester University,1985).

${ }^{77}$ Bamford, Passages, ch. 5. Pickering argues that there was very little popular Cromwellianism in the Chartist movement: Pickering, 'The hearts of millions', 230-3. ${ }^{78}$ Semmel, Napoleon and the British.

${ }^{79}$ Belchem and Epstein, 'Gentlemanly radicals'; Thompson, Making of the English Working Class, pp. 682-3.

${ }^{80}$ Paul Pickering, Feargus O'Connor: a Political Life (Monmouth: Merlin Press, 2008), ch. 1 \& p. 149; Pickering, 'The Hearts of the Millions', 24.

${ }^{81}$ Taylor, Ernest Jones, pp. 19, 44-5.

${ }^{82}$ Navickas, 'The search for "General Ludd”', 294.

${ }^{83}$ Semmel, Napoleon and the British, pp. 13-14. On the breadth of wartime patriotism, extending after 1803 to radical constituencies, see Peter Spence, The Birth of Romantic Radicalism: War, Popular Politics and English Radical Reformism, 1800-1815 (Aldershot: Scolar, 1996), and Jennifer Mori, 'Languages of Loyalism: Patriotism, Nationhood and the State in the 1790s', English Historical Review (Feb. 2003), 33-58.

${ }^{84}$ Peter Linebaugh, The London Hanged (London: Allen Lane, 1991), 347; John Belchem, '1848: Feargus O'Connor and the collapse of the mass platform', in The Chartist Experience, ed. by James Epstein \& Dorothy Thompson (London: Macmillan, 1982), 290; Marc Brodie, 'Free trade and cheap theatre: sources of politics for the nineteenth-century poor', Social History 28, 3 (Oct. 2003), 346-8. 